\title{
ガイドラインから見たベプリジルの位置づけ
}

\section{Positioning of Bepridil in the Guidelines for Pharmacotherapy of Atrial Fibrillation}

心房細動 (AF) に対する包括的アプローチが求められるなか, 本邦でも J-RHYTHM, J-BAF試験などのエビデンスが集積され，それを受けた新しいガイドラインが示さ れた。そこではまず抗血栓療法を重視し, 孤立性発作性 AFでは $\mathrm{Na}^{+}$チャネル遮断 薬によるリズム治療を推奨した．この点は基本的に海外のガイドラインと変わりな いが，持続性 AFや病的心に伴うAFに対する治療薬については海外でも混乱をき たしている. ドロネダロンが一時期, 有力な選択肢となつていたが, その危険性が 指摘され，心不全例においては急速にその支持を失いつつある. 病的心に伴う AF に対しては, アミオダロン, ソタロール, ドフェチリドなどの $\mathrm{K}^{+}$チャネル遮断薬 もリズム治療薬として推奨されているが, 本邦では $\mathrm{K}^{+}$チャネル遮断作用に加え, リモデリングを逆転させる作用などによつて高い抗 AF 効果をもつベプリジルが, 新たな選択肢として注目されている.しかしながら, $\mathrm{K}^{+}$チャネル遮断作用は心室 筋にも影響を与え, QT延長を促進させるため, torsade de pointesなど致死性催 不整脈作用をもたらすことがある. 特に器質的心疾患例ではその危険性が増すこと が知られており, 細心の注意を払いながらその高い効果の発現を促す工夫が求めら れる.

\section{I ．心房細動ガイドラインの変遷}

心房細動 $(\mathrm{AF})$ の治療が画一的に行えないもので あることは多くの医師が経験し，感じている．複雑 な $\mathrm{AF}$ を相手に，医師個人の知識や経験に照らし合 わせながら治療を選択し提供する，というやり方で は当然限界がある。ガイドラインが必要とされる所 以はそこにある。

本邦初の $\mathrm{AF}$ 治療ガイドラインが誌上に掲載され たのは 2001 年のことであるが ${ }^{1)}$, 同じ年に海外で も ACC/AHA/ESC 合同のガイドラインが発表され
た $^{2)}$. 翌 2002 年には AFFIRM試験の結果が発表さ れ，レート治療への回帰がセンセーショナルに叫ば れた ${ }^{3)}$. しかしながら，本邦で 2006 年に発行され た改訂版ガイドラインでは, AFの持続が 1 年未満, 左房径が $5 \mathrm{~cm}$ 未満, 除細動歴が 1 回以内で，かつ 患者が希望すればリズム治療の選択も容認された. この時点では, ベプリジルは除細動薬ではなく再発 予防薬として位置づけられていた。一方，徐々にで はあったが，高周波カテーテルアブレーションによ る肺静脈隔離術が発展し，2006年に発表された $\mathrm{ACC} / \mathrm{AHA} / \mathrm{ESC}$ ガイドラインでは, アブレーショ

東京都済生会中央病院心臓病臨床センター ( ₹ 108-0073 東京都港区三田 1-4-17)

Hideo Mitamura

・Keywords ; 心房細動, ガイドライン, 抗不整脈薬, ベプリジル 
ンが薬物療法に続く選択肢として明記されている ${ }^{4)}$.

近年，本邦ではJ-RHYTHM，J-BAF と呼ばれる

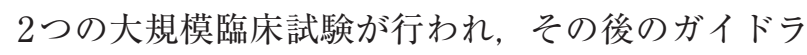
インに影響を与えた ${ }^{5)}$,6). J-RHYTHM試験では, 発作性 $\mathrm{AF}$ の場合にはリズム治療が有用であること が示され，ピルジカイニド，シベンゾリン，プロパ フェノンなどの比較的強力な $\mathrm{Na}^{+}$チャネル遮断薬の 有効性が示された。 反対に，持続性 AFに対しては レート治療がより好まれた。持続性であってもリズ ム治療におけるべプリジルの可能性がより注目を集 めるようになったのは, J-BAF 試験の結果が報告さ れてからである。この J-BAF 試験では 1 週間以上 持続した $\mathrm{AF}$ に対するべプリジルの停止効果が，1 日 $100 \mathrm{mg}$ 投与では 37.5\%，200 mg 投与では $69.0 \%$ に達することが示された。この結果を受けて，持続性 $\mathrm{AF}$ に対するべプリジルの保険承認が 2008年 11 月 に得られ,ガイドラインも改訂されることとなった ${ }^{7)}$.

2008年ガイドライン改訂版では, 孤立性発作性 AFにはJ-RHYTHM 試験で確認された $\mathrm{Na}^{+}$チャネ ル遮断薬によるリズム治療を第一適応とした (図 1，2).しかし，持続性 AFに対してはレート 治療を基本戦略と位置づけながらも，リズム治療が 望まれて試みる際には，リモデリングした心房筋で は効果が減弱する $\mathrm{Na}^{+}$チャネル遮断薬よりも $\mathrm{K}^{+}$ チャネル遮断作用を有する薬剤を優先し，ここに J-BAF試験で使われたべプリジルが含まれた。ま た，器質的病的心においては，レート治療か $\mathrm{K}^{+}$チャ ネル遮断作用を有する薬剤を選択肢とした。病的心 におけるべプリジルの効果についてはエビデンスが 十分とはいえないものの, $\mathrm{K}^{+}$チャネル遮断薬につ いてのエビデンスは海外の臨床試験により集積さ れ，海外のガイドラインに組み达まれている.

海外では2010年 8 月にヨーロッパ心臟会議 (ESC) ガイドラインが改訂されたのを皮切りに，同年 12 月には ACCF/AHA/HRSガイドラインの一部が, さらに2011年 2 月にはカナダ心臓血管会議 (CCS) ガイドラインも改訂された ${ }^{8) ~ 10)}$ ，その主な変更点 は抗凝固療法についてのアップデートであったが,

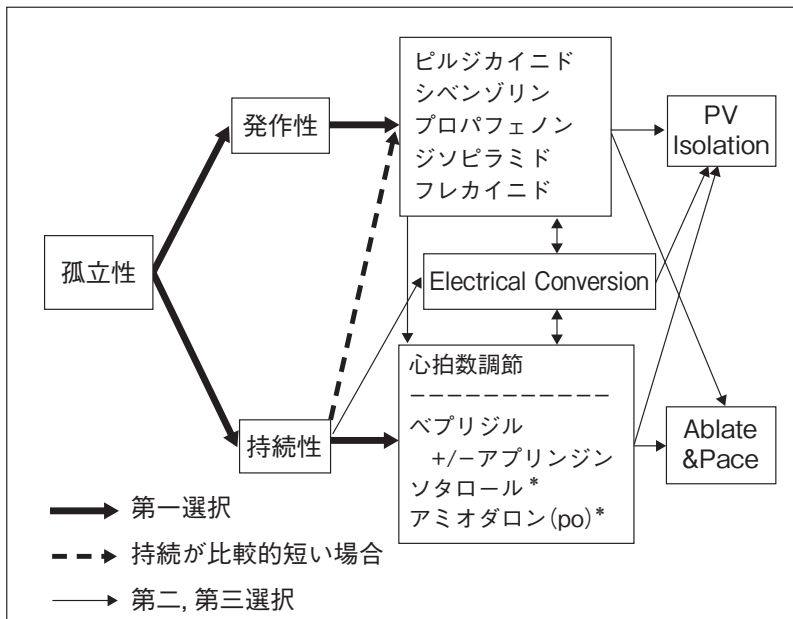

発作性とは7 日以内に自然停止するもの. 持続性はそれ以上持 続するものを指す.

Ablate\&Pace $=$ 房室接合部アブレーション十心室ペーシング, *: 保険適用なし

太線で示された矢印が第一選択. 持続性の場合の第一選択は 心拍数調節であるが, 保険適用の範囲を超えて除細動を追求す る場合には, 破線以下の薬剤が候補となる(これらの薬剤には徐 拍作用があるが，心拍数コントロールのための薬剂と併用する こともある). 心拍数調節が十分に達成できないか, さらなる症 状軽減が必要なために除細動を追求する場合にも, 同様に破線 以下の薬剂が候補となりうる。このいずれかの方法が，あるい はその両者が無効なときに, 細い矢印に沿って第二選択肢とし て非薬物療法である電気ショック, 肺静脈アブレーション, 房 室接合部アブレーションなどが考慮される.

なお持続性でも比較的持続期間の短い例では $\mathrm{Na}$ チャネル遮断 薬を最初に試すこともあり, その選択肢を破線矢印で示したが, 発作性に対して心拍数調節や破線以下の薬剤を第一選択として 使うことはない，発作性心房細動に対する第一選択薬が無効な 場合の第 2 選択肢を限定することはしないが, 手技に熟練した 施設では肺静脈アブレーションが有力候補となる.

* 脚注 : 前ガイドラインで心機能正常例での第一選択薬として いた 5 種類の slow kineticの Naチャネル遮断薬の中から, 現在, 将来とも保険適用となる見込みのない薬剂(ピルメノール)を除 外し, 逆に ACC/AHA/ESC ガイドラインでも第一選択薬とされ ているプロパフェノンを加えた. プロパフェノンは実験的には slow kineticではなく intermediate とされるが, lto (一過性 K電流) や I Kur (遅延整流 K 電流の特に速い成分) などを抑制する作用も知 られており, 臨床的にも他の intermediate kinetic の薬剤と比較 して有効性/安全性についての十分なエビデンスがある(JRHYTHM試験での使用実積もある)ことから, 敢えて他の slow kineticのNaチャネル遮断薬と同列に扱うことにした. 一方, ア ミオダロン(経ロ), ソタロールは心房細動への適応拡大に向け た手続きが進行中であるためリストに残した.

図 1 孤立性心房細動に対する治療戦略

〔文献 7)上り引用〕 


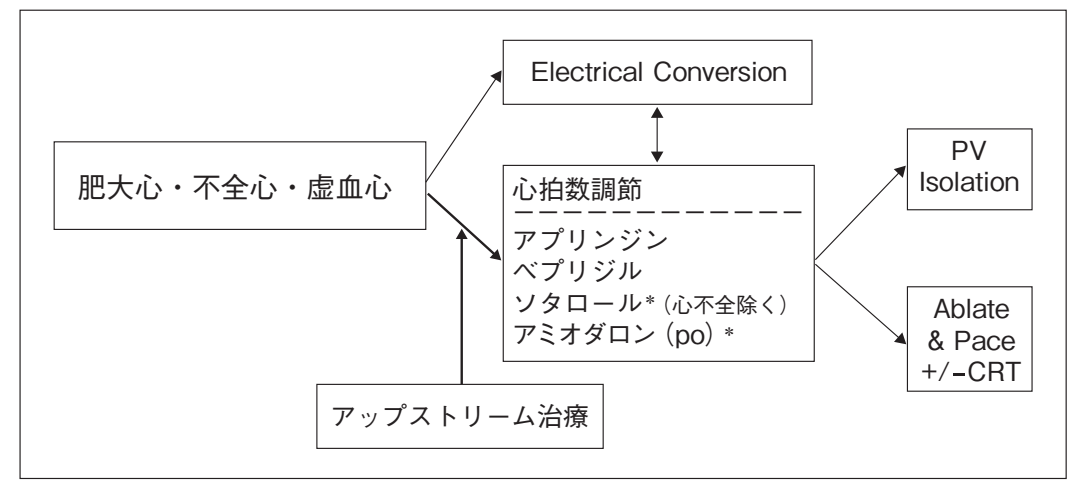

図 2

器質的病的心(肥大心・不全心・虚血心) に伴う心房細動に対する治療戦略

Ablate\&Pace $=$ 房室接合部アブレーション+ 心室ペーシング, $\mathrm{CRT}=$ 心室同期ペーシング

*: 保険適用なし(ただし肥大型心筋症に対す る経ロアミオダロンと持続性心房細動に対 するべプリジルは適用あり)

〔文献 7)上り引用〕

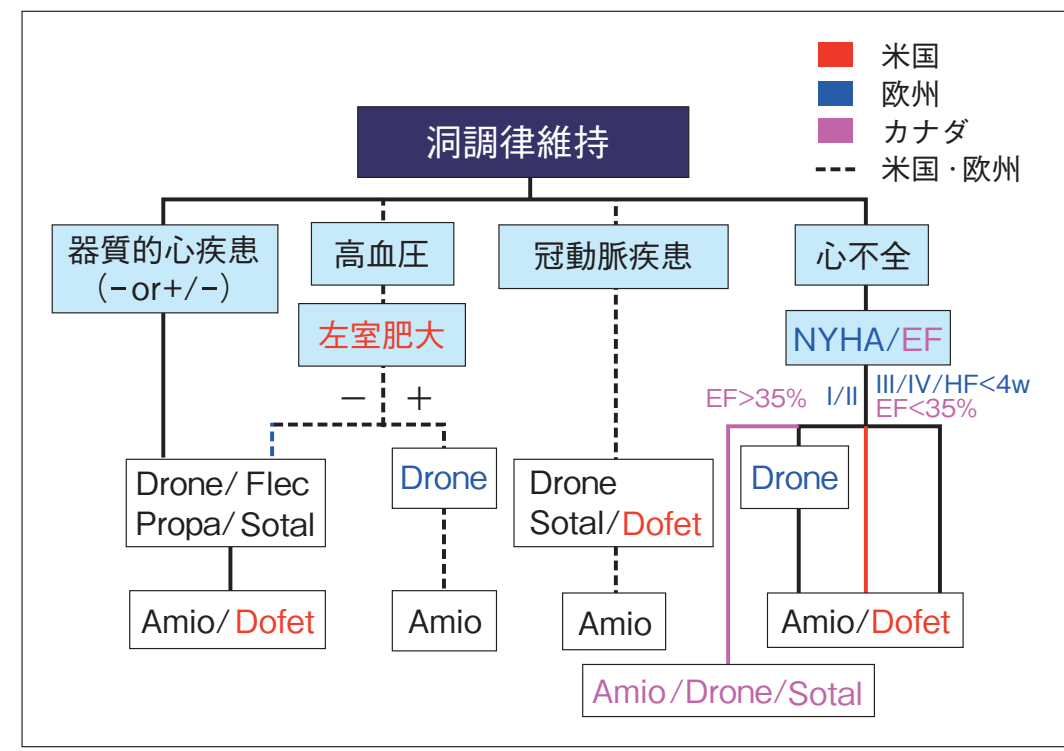

\section{図 3}

2010年以降に発表された国際ガイドラ イン

Drone : dronedarone, Flec : flecainide, Propa : propafenone, Sotal : sotalol, Amio : amiodarone, Dofet : dofetilide

〔文献 8)～10)上り引用改変〕

もうひとつのポイントは器質的心疾患におけるリズ ム治療薬についてであった(図 3)。従来, この群に おいてはアミオダロンが選択薬の中心となってきた が, ATHENA 試験の結果を受けて ${ }^{11)}$ ，マルチチヤ ネル遮断薬であるドロネダロンの適応が拡大され， ほとんどすべての器質的心疾患に伴う AFに対する 第一選択薬のひとつとして受け入れられた。 ところ が，重症心不全例においてドロネダロンが心不全を 悪化させて死亡率を高めたことを報告した ANDROMEDA 試験の結果を受けて ${ }^{12)}, \mathrm{ACCF} /$ AHA/HRSガイドラインでは心不全例と, 著明な心 肥大を伴う高血圧例に対してはドロネダロンとソタ ロールを適応としていない. 同様に ESCでも NYHA III / IV の例，CCSでは左室駆出率＜35\%の例 にはドロネダロンをすすめていない ${ }^{12)}$ 。さらに最
近, PALLAS試験の結果が発表され，高齢者で比 較的心血管リスクの高い慢性 AF 例へのドロネダロ ン投与が除細動効果をほとんど示さなかっただけで なく, 短期間のうちに心不全, 脳卒中例を増やし, 主に不整脈による死亡率を増加させることがわかっ た ${ }^{13)}$. そのため, この薬剤への期待は急速に冷め つつある。

\section{II. 心房細動に対する $\mathrm{K}^{+}$チャネル遮断薬の 位置づけ}

$\mathrm{ACCF} / \mathrm{AHA} / \mathrm{HRS}$ ガイドラインでは, 器質的障 害が軽微な例や冠動脈疾患例には $\beta$ 遮断作用をあわ せもつ $\mathrm{I}_{\mathrm{Kr}}$ 遮断薬ソタロールをすすめているが, こ れはSAFE-T試験の結果に基づく。この試験は 72 時間以上持続する $\mathrm{AF}$ 例を対象に，アミオダロン, 


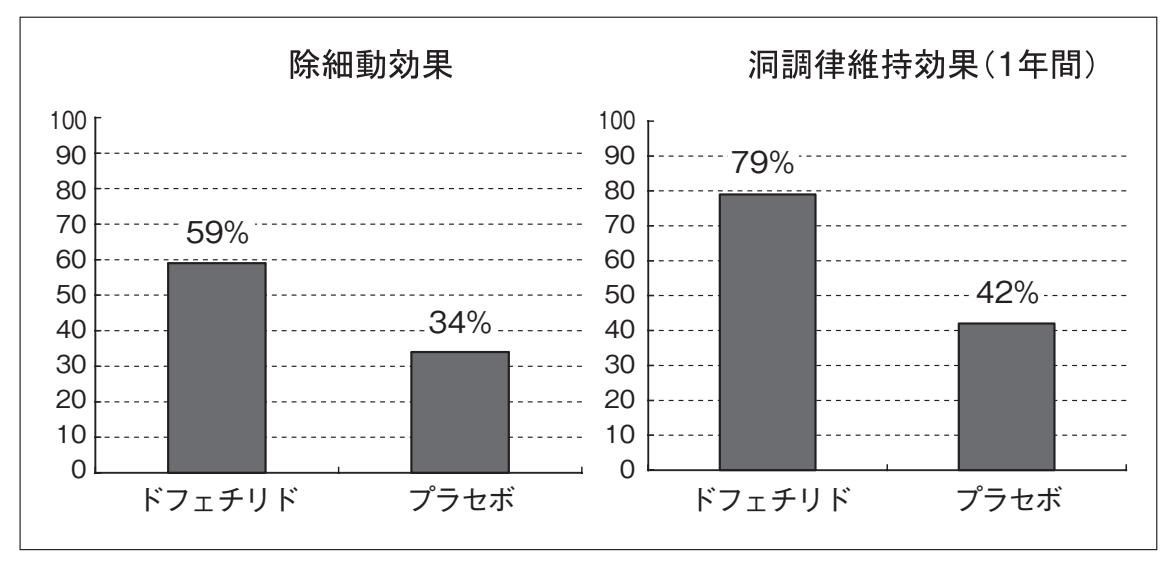

図 4 心不全例における $\mathrm{K}^{+}$チャネル遮断 薬ドフェチリドの抗心房細動効果 (DIAMOND)

〔文献 15）上り引用改変〕

ソタロール，プラセボの 3 群比較を試みたものであ るが，28日以内の自然停止率はそれぞれ $27.1 \%$, $24.2 \%, 0.8 \%$, 除細動後の再発までの期間は 487 日, 74 日， 6 日，1年後洞調律維持率は $52 \%, 32 \%$, $13 \%$ でった ${ }^{14)}$. 再発予防率はアミオダロンの方 がソタロールよりも有効であったが $(\mathrm{p}<0.001)$, 虚 血性心疾患例では有意差を認めなかった。この事実 が冠動脈疾患例におけるソタロールの存在価值を高 めたものと推察される.

また, ACCF/AHA/HRSガイドラインでは, pure $\mathrm{I}_{\mathrm{Kr}}$ 遮断薬ドフェチリドを著明な心肥大を伴う 高血圧例以外に適応としている点も興味深く，心不 全例や冠動脈疾患例では第一適応となっている.こ れは主に, DIAMOND 試験サブ解析の結果を反映 したものである。この試験では NYHA III / IV の心 不全か最近の心筋梗塞の既往を有し, 登録時に $\mathrm{AF} /$ 心房粗動 (AFL)を合併していた 506 例を 2 群に 分けて除細動効果と洞調律維持効果を比較している (図 4) ${ }^{15)}$. 1 1 月後にドフェチリド群の $12 \%$ ，プラ セボ群の $2 \%$ が洞調律に復帰し $(\mathrm{p}<0.001)$, 全治療 期間中では前者の $59 \%$, 後者の $34 \%$ が洞調律に復 帰した。さらに洞調律に復したすべての例につい て, 1 年後にも洞調律が維持できていたのはドフェ チリド群の $79 \%$, プラセボ群の $42 \%$ あっった $(\mathrm{p}<0.001)$.この試験では当然ながら torsade de pointes (TdP)の合併を減らすべく配慮がされてお り, QTc $>460 \mathrm{msec}$ (脚ブロック例では>500 $\mathrm{msec}$ ),
覚醒時心拍数 $<50 \mathrm{bpm}$, 血清 $\mathrm{K}^{+}<3.6 \mathrm{mEq} / \mathrm{L}, \mathrm{CrCL}<$ $20 \mathrm{~mL} /$ 分などの例を除外しているほか, 服薬開始 後 72 時間の入院連続心電図モニターを義務づけて いる.その結果, ドフェチリド投与開始 2 日後に 2 名, 8 日目に 1 名, 13 日目に 1 名の TdPを認めたが (1.6\%)，それによる死亡はなかった.

特に心不全例に合併する AFにドフェチリド，つ まり $\mathrm{K}^{+}$チャネル遮断薬が有効であることは動物実 験でも支持されている，Liらはイヌを用い，220〜 240 bpm の心室ペーシングを 5 週間行って作成した 心不全モデルと, $400 \mathrm{bpm}$ の心房ペーシング $(+$ 房 室ブロック+心室ペーシング $80 \mathrm{bpm})$ を 1 週間行っ た心房頻拍モデルにおける心房バースト刺激による $\mathrm{AF}$ 誘発を試み, ドフェチリドの効果を調べた $(\text { 図 5 })^{16)}$. 無投薬下で AFは同等の持続を示したが, ドフェチリドによる $\mathrm{AF}$ 停止効果や再発予防効果は 心不全モデルにおいてのみ発揮され, 心房頻拍モデ ルでは認められなかった. 電気生理学的には伝導速 度についてはいずれのモデルも違いなく，またド フェチリド投与後も変化を認めなかった。しかし, 心房不応期は心不全モデルの心房で無投薬時から有 意に長く，それがドフェチリドによって心房頻拍モ デルにおいて認められた以上にさらに延長した。 マッピングでは心房頻拍モデルの AF は主にミクロ リエントリーによるものであるのに対し，心不全モ デルの AFはマクロリエントリーによるもので ${ }^{17)}$, そ れがドフェチリドの作用でブロックされることが確 


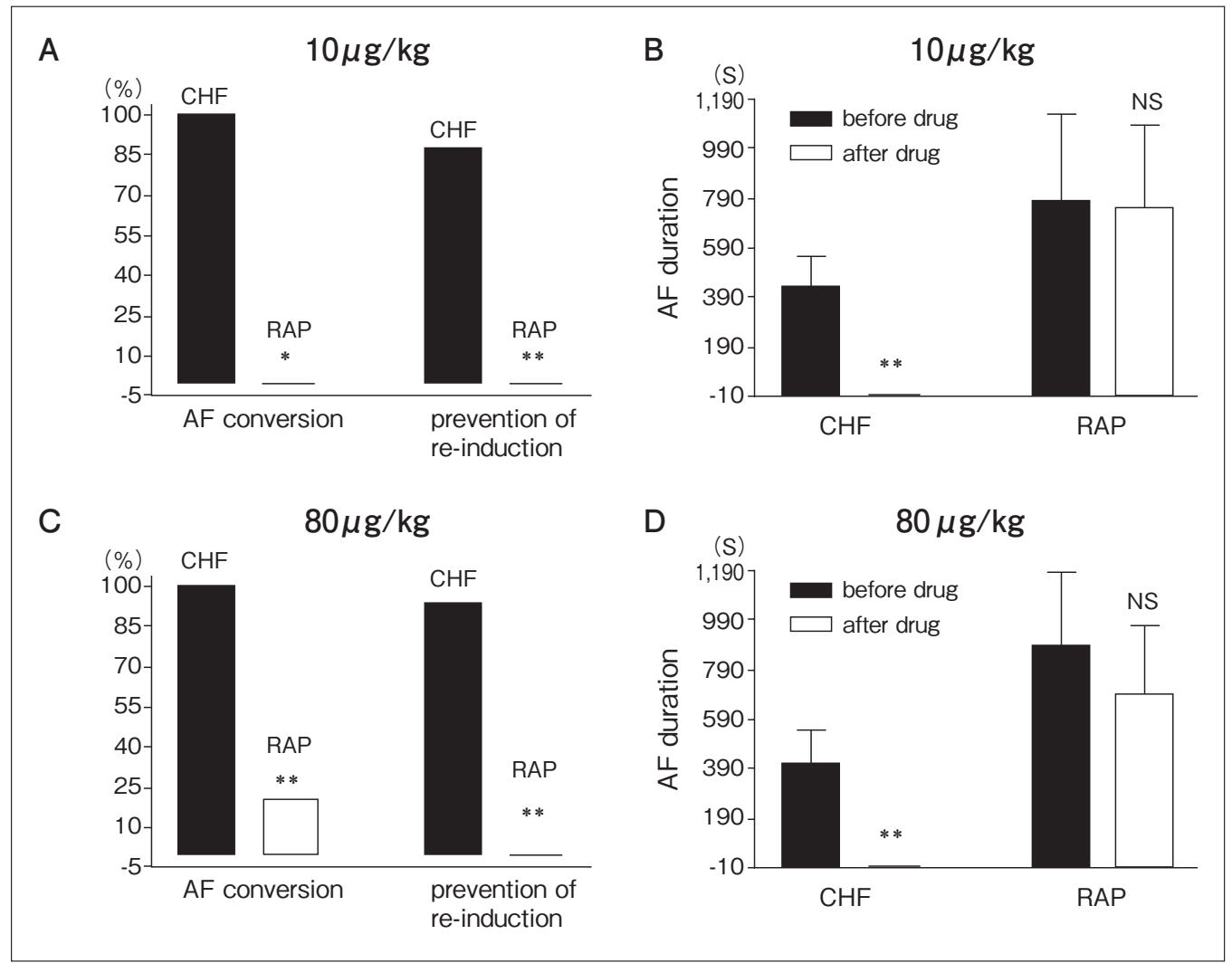

図 5 イヌ心不全モデル(CHF) および心房頻拍モデル(RAP)におけるドフェチリド 2 用量による心房細動停止効果, 再誘発阻止効果, 心房細動持続時間の比較

〔文献 16）より引用改変]

かめられた. ベプリジルにも $\mathrm{I}_{\mathrm{Kr}}$ 遮断作用が存在す るが, AFに対して示しうる作用はそれだけではない.

\section{III 。抗心房細動作用に貢献するべプリジルの 多チャネル遮断作用}

1. $\mathrm{Na}^{+}$チャネル遮断作用が弱いことの意義

前述したような心不全例に発生した $\mathrm{AF}$ に対し, 伝導抑制作用を主作用とする $\mathrm{Na}^{+}$チャネル遮断薬は ますますリエントリーを促進するだけで，停止効果 は極めて弱い. 加えて, $\mathrm{Na}^{+}$チャネル遮断薬は心不 全を悪化させる危険もある. SPAF 試験によれば, 心不全を合併した $\mathrm{AF}$ 例では I 群抗不整脈薬を服薬 した群のほうがしない群よりも，心死亡率が 4.7 倍 高くなるが，心不全の合併がなければ両者の間には 有意差を認めなかったという ${ }^{18)}$. したがって，心 不全に伴う AFに対しては, 除細動目的であろうと,
再発予防目的であろうと，これらの抗不整脈薬を用 いることはすすめられない. ベプリジルの $\mathrm{Na}^{+}$チャ ネル遮断作用が弱い特性は，このような病的心にお ける有害事象を回避するうえで有益と考えられる。

\section{2. $\mathrm{K}^{+}$チャネル遮断作用の可能性}

前述したように，基礎実験と臨床試験のエビデン スから, $\mathrm{K}^{+}$チャネル遮断薬が特に心不全例や虚血 性心疾患例に伴う AFに有効であることは容認で き，その点で $\mathrm{I}_{\mathrm{Kr}}$ 遮断作用を有するべプリジルにも 同等の効果が期待できる。一方でベプリジルの QT 延長作用は徐々に進行し，およそ 3 週間後にピーク に到達することから，投与開始当初の入院モニタリ ングではその回避を保証できず，外来における QT や血清 $\mathrm{K}^{+}$の監視がより重要となる。また後述する ように, ベプリジルには徐拍作用もあるため, これ が $\mathrm{K}^{+}$チャネルの逆頻度依存性ブロックを助長する 


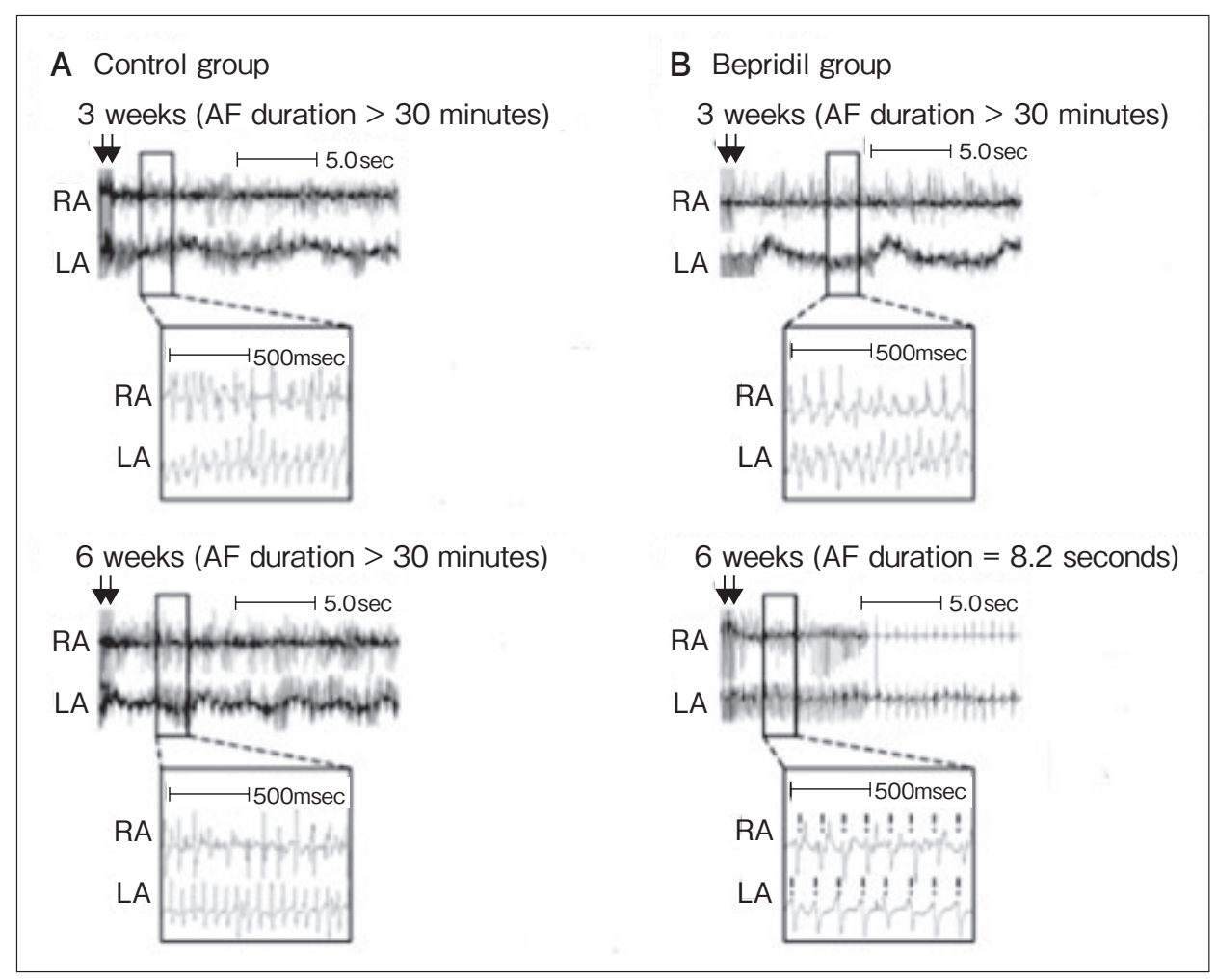

図 6 イヌ心房高頻度刺激モデルにおけるベプリジルによるリバースリモデリング 高頻度バース卜刺激 (矢印)による心房細動誘発時の右房 $(\mathrm{RA})$ 㧍よび左房 (LA)の心房電位図. A：400/分，6週間刺激，B：400/分，3週間刺激後に刺激を続けながらベプリジル $10 \mathrm{mg} /$ $\mathrm{kg} /$ 日を投与.

〔文献 21)より引用改変〕

危険のあることも認識していなければならない ${ }^{19)}$. $\mathrm{K}^{+}$チャネル遮断薬を $\mathrm{AF}$ 中に投与する際には QT の 評価が比較的困難なため, 見落としのないように十 分な注意が払われる必要がある ${ }^{20)}$.

\section{3. $\mathrm{Ca}^{2+}$ チャネル遮断作用の有用性}

\section{a) 徐拍作用}

ベプリジルの徐拍効果は，動悸や息切れを減らす のみならず，頻脈誘発性心筋症を防止する効果も期 待できる. 実験で示されたように，心室頻回刺激に よる心房の線維化は $\mathrm{AF}$ を起こしやすくすることか ら, 心室のレート治療自体が，二次予防でありなが ら心房の不整脈器質の進展を阻止する upstream 治 療の役割も果たすと考えられる.

b) リバースリモデリング作用

ベプリジルによる除細動の特徵は洞調律への復帰 が投与開始後早期ではなく, 数週間以上経過してか
らみられることである.

Nishidaらは房室ブロック犬を用い，3週間の心 房高頻度刺激の後に, 刺激はそのまま続けながらべ プリジル $10 \mathrm{mg} / \mathrm{kg} /$ 日を 3 週間投与したイヌと， 刺激のみ 6 週間行ったコントロール犬とを比較し た.すると, 投与したイヌでは一度短縮した心房不 応期が再び延長し，一度増加した $\mathrm{AF}$ 誘発率が低下 した。これは心房の電気的リモデリングが逆進行し た可能性を示唆している(図6) ${ }^{21)}$. 同時に彼らは, L 型 $\mathrm{Ca}^{2+}$ チャネルをコードする $\alpha_{1 \mathrm{c}} \mathrm{mRNA}$ の発現 がコントロール犬では $64 \%$ 減ったのに対し， ベプ リジル投与犬ではシャム犬と変わらなかったと述 べ，この機序の意義を重視している. 


\section{IV. ベプリジルの将来的位置づけ}

持続性 AFに対しては, J-RHYTHM試験で示さ れたエビデンスを重視すれば，基本的にレート治療 が第一選択となる。しかし，なかには除細動が望ま れる場面もあり，そのような例において高い除細動 効果を示すべプリジルが役に立つと考えられる，具 体的には，(1)喘息で $\beta$ 受容体刺激薬を必要とするな どレート治療が十分にできない場合，(2)肥大型心筋 症など拡張能が低下し，レート治療を行っても動悸 や心不全症状が改善しない場合，(3)初発の孤立性持 続性 $\mathrm{AF}$ で除細動後の洞調律維持が期待できる場 合，(4)甲状腺機能立進や僧帽弁狭窄症などの治療後 で背景因子が除去されている場合，(5)抗凝固薬の適 応例だが潰瘍性大腸炎や原因不明の鉄欠乏性貧血が あるなど出血傾向を認める場合や，TIA や薬剂溶 出ステント (DES) 留置後などのため抗血小板の服 用が避けられない場合, (6)洞調律復帰後に肺静脈ア ブレーションを行うことにより成功率の向上が期待 できる場合，などである。

このような例に対する除細動には電気的除細動の 成功率が高いが，再発を抑えるにはしばしば薬剤が 必要となる。ところが，リズム治療のための $\mathrm{Na}^{+}$ チャネル遮断薬の効果は 1 週間を超えると激減す る. 持続性 $\mathrm{AF}$ の薬理学的停止については海外から はアミオダロン，ソタロールなどの効果も報告され ているが ${ }^{14)}$ ，本邦には J-BAF 試験で高い除細動効 果が証明されたべプリジルがあり，実際にその要求 に応えている ${ }^{6)}$.

ベプリジルを選択するにあたってとくに悩ませら れるのは，対象が病的心の場合である。線維化が進 んだ病的心においてべプリジルがドフェチリド同様 の抗 $\mathrm{AF}$ 効果を発揮する可能性がある反面, $\mathrm{I}_{\mathrm{Kr}}$, $\mathrm{I}_{\mathrm{Ks}}, \mathrm{I}_{\mathrm{to}}$ などがすでに減少している病的心室筋にお いては，活動電位を一層延長して早期後脱分極から TdPを誘発する危険も同時に高まる。ここにおい てベプリジルは両刃の剣といえる。抗不整脈作用に よるメリットと催不整脈作用によるデメリットを比
べて得られる net clinical benefitは患者ごとに異な り, 一律にガイドラインとして推奨するものでも禁 じるものでもない.

ベプリジルの持続性 $\mathrm{AF}$ に対する効果は他剤では 得られない恩恵を患者にもたらす可能性があり，そ の存在意義は大きい。この特異的な作用機序につい ての究明はいまだ十分とはいえず，その解明こそ が，より安全性の高い薬剤の開発につながるものと 期待される.

\section{〔文献〕}

1) 循環器病の診断と治療に関するガイドライン研究班： 心房細動治療(薬物) ガイドライン $(1999$ ～2000年度合同 研究班報告).Jpn Circ J, $2001 ; 65$ (Suppl IV) ：931〜 978

2 ) Fuster V, Rydén LE, Asinger RW, Cannom DS, Crijns HJ, Frye RL, Halperin JL, Kay GN, Klein WW, Lévy S, McNamara RL, Prystowsky EN, Wann LS, Wyse DG, Gibbons RJ, Antman EM, Alpert JS, Faxon DP, Fuster V, Gregoratos G, Hiratzka LF, Jacobs AK, Russell RO, Smith SC Jr, Klein WW, Alonso-Garcia A, BlomströmLundqvist C, de Backer G, Flather M, Hradec J, Oto A, Parkhomenko A, Silber S, Torbicki A ; American College of Cardiology/American Heart Association Task Force on Practice Guidelines ; European Society of Cardiology Committee for Practice Guidelines and Policy Conferences (Committee to Develop Guidelines for the Management of Patients With Atrial Fibrillation); North American Society of Pacing and Electrophysiology : ACC/AHA/ESC Guidelines for the Management of Patients With Atrial Fibrillation: Executive Summary A Report of the American College of Cardiology/American Heart Association Task Force on Practice Guidelines and the European Society of Cardiology Committee for Practice Guidelines and Policy Conferences (Committee to Develop Guidelines for the Management of Patients With Atrial Fibrillation) Developed in Collaboration With the North American Society of Pacing and Electrophysiology. Circulation, 2001; 104(17) : $2118 \sim 2150$

3) Wyse DG, Waldo AL, DiMarco JP, Domanski MJ, Rosenberg Y, Schron EB, Kellen JC, Greene HL, Mickel MC, Dalquist JE, Corley SD ; Atrial Fibrillation Follow-up Investigation of Rhythm Management (AFFIRM) Investigators: A comparison of rate control and rhythm control in patients with atrial 
fibrillation. N Engl J Med, $2002 ; 347(23)$ : 1825 1833

4) ACC/AHA/ESC 2006 Guidelines for the Management of Patients with Atrial Fibrillation : Executive Summary. Circulation, $2006 ; 114: 700 \sim 752$

5 ) Ogawa S, Yamashita T, Yamazaki T, Aizawa Y, Atarashi H, Inoue $\mathrm{H}$, Ohe $\mathrm{T}$, Ohtsu H, Okumura $\mathrm{K}$, Katoh T, Kamakura S, Kumagai K, Kurachi Y, Kodama I, Koretsune Y, Saikawa T, Sakurai M, Sugi K, Tabuchi T, Nakaya H, Nakayama T, Hirai M, Fukatani M, Mitamura H ; J-RHYTHM Investigators : Optimal treatment strategy for patients with paroxysmal atrial fibrillation : J-RHYTHM Study. Circ J, 2009 ; 73(2) : $242 \sim 248$

6 ) Yamashita T, Ogawa S, Sato T, Aizawa Y, Atarashi H, Fujiki A, Inoue $\mathrm{H}$, Ito $\mathrm{M}$, Katoh $\mathrm{T}$, Kobayashi $\mathrm{Y}$, Koretsune Y, Kumagai K, Niwano S, Okazaki O, Okumura K, Saku K, Tanabe T, Origasa H ; J-BAF Investigators : Dose-response effects of bepridil in patients with persistent atrial fibrillation monitored with transtelephonic electrocardiograms : a multicenter, randomized, placebo-controlled,doubleblind study (J-BAF Study). Circ J, 2009; 73(6) : $1020 \sim 1027$

7 ) 循環器病の診断と治療に関するガイドライン研究班 : 心房細動治療 (薬物) ガイドライン (2008年改訂版) . Circ J, $2008 ; 72$ (Suppl IV) : 1581〜 1638

8 ) European Heart Rhythm Association ; European Association for Cardio-Thoracic Surgery, Camm AJ, Kirchhof P, Lip GY, Schotten U, Savelieva I, Ernst S, Van Gelder IC, Al-Attar N, Hindricks G, Prendergast B, Heidbuchel H, Alfieri O, Angelini A, Atar D, Colonna P, De Caterina R, De Sutter J, Goette A, Gorenek B, Heldal M, Hohloser SH, Kolh P, Le Heuzey JY, Ponikowski P, Rutten FH : Guidelines for the management of atrial fibrillation : the Task Force for the Management of Atrial Fibrillation of the European Society of Cardiology (ESC) . Eur Heart J, 2010 ; 31 (19) : $2369 \sim 2429$

$9)$ Wann LS, Curtis AB, January CT, Ellenbogen KA, Lowe JE, Estes NA 3rd, Page RL, Ezekowitz MD, Slotwiner DJ, Jackman WM, Stevenson WG, Tracy CM ; 2011 Writing Group Members, Fuster V, Rydén LE, Cannom DS, Le Heuzey JY, Crijns HJ, Lowe JE, Curtis AB, Olsson SB, Ellenbogen KA, Prystowsky EN, Halperin JL, Tamargo JL, Kay GN, Wann LS ; 2006 Writing Committee Members, Jacobs AK, Anderson JL, Albert N, Hochman JS, Buller CE, Kushner FG, Creager MA, Ohman EM, Ettinger SM, Stevenson WG, Guyton RA, Tarkington LG, Halperin JL, Yancy CW ; ACCF/AHA Task Force Members :
$2011 \mathrm{ACCF} / \mathrm{AHA} / \mathrm{HRS}$ focused update on the management of patients with atrial fibrillation (updating the 2006 guideline): a report of the American College of Cardiology Foundation/American Heart Association Task Force on Practice Guidelines. Circulation, $2011 ; 123(1): 104 \sim 123$

10) Gillis AM, Verma A, Talajic M, Nattel S, Dorian P ; CCS Atrial Fibrillation Guidelines Committee : Canadian Cardiovascular Society atrial fibrillation guidelines 2010 : rate and rhythm management. Can J Cardiol, $2011 ; 27(1): 47 \sim 59$

11) Hohnloser SH, Crijns HJ, van Eickels M, Gaudin C, Page RL, Torp-Pedersen C, Connolly SJ ; ATHENA Investigators : Effect of dronedarone on cardiovascular events in atrial fibrillation. N Engl J Med, $2009 ; 360$ (7) : $668 \sim 678$

12) Køber L, Torp-Pedersen C, McMurray JJ, Gøtzsche O, Lévy S, Crijns H, Amlie J, Carlsen J ; Dronedarone Study Group : Increased mortality after dronedarone therapy for severe heart failure. N Engl J Med, 2008 ; 358(25) : 2678 2687

13) Connolly SJ, Camm AJ, Halperin JL, Joyner C, Alings M, Amerena J, Atar D, AvezumÁ, Blomström P, Borggrefe M, Budaj A, Chen SA, Ching CK, Commerford P, Dans A, Davy JM, Delacrétaz E, Di Pasquale G, Diaz R, Dorian P, Flaker G, Golitsyn S, Gonzalez-Hermosillo A, Granger CB, Heidbüchel H, Kautzner J, Kim JS, Lanas F, Lewis BS, Merino JL, Morillo C, Murin J, Narasimhan C, Paolasso E, Parkhomenko A, Peters NS, Sim KH, Stiles MK, Tanomsup S, Toivonen L, Tomcsányi J, Torp-Pedersen C, Tse HF, Vardas P, Vinereanu D, Xavier D, Zhu J, Zhu JR, Baret-Cormel L, Weinling E, Staiger C, Yusuf S, Chrolavicius S, Afzal R, Hohnloser SH ; PALLAS InvestigatorsDronedarone in high-risk permanent atrial fibrillation. N Engl J Med, 2011 ; $365(24)$ : $2268 \sim 2276$

14) Singh BN, Singh SN, Reda DJ, Tang XC, Lopez B, Harris CL, Fletcher RD, Sharma SC, Atwood JE, Jacobson AK, Lewis HD Jr, Raisch DW, Ezekowitz MD ; Sotalol Amiodarone Atrial Fibrillation Efficacy Trial (SAFE-T) Investigators : Amiodarone versus sotalol for atrial fibrillation.N Engl J Med, 2005 ; 352 (18) : $1861 \sim 1872$

15) Pedersen OD, Bagger H, Keller N, Marchant B, Køber L, Torp-Pedersen C : Efficacy of dofetilide in the treatment of atrial fibrillation-flutter in patients with reduced left ventricular function : a Danish investigations of arrhythmia and mortality on dofetilide (diamond) substudy.Circulation, $2001 ; 104$ (3): 
$292 \sim 296$

16) Li D, Bénardeau A, Nattel S : Contrasting efficacy of dofetilide in differing experimental models of atrial fibrillation. Circulation, $2000 ; 102(1): 104 \sim 112$

17) Li D, Fareh S, Leung TK, Nattel S : Promotion of atrial fibrillation by heart failure in dogs : atrial remodeling of a different sort.Circulation, $1999 ; 100(1): 87 \sim 95$

18) Predictors of thromboembolism in atrial fibrillation : I. Clinical features of patients at risk. The Stroke Prevention in Atrial Fibrillation Investigators. Ann Intern Med, $1992 ; 116(1): 1 \sim 5$

19) Sadanaga T, Ogawa S : Bepridil produces prominent bradycardia-dependent QT prolongation in patients with structural heart disease.J Electrocardiol, 2007 ; 40 (5) : 426 431

20) Mitamura $\mathrm{H}$ : Prevention of Torsade de pointes during the pharmacologic treatment of atrial fibrillation. J Arrhythmia, $2010 ; 26: 5 \sim 15$

21) Nishida K, Fujiki A, Sakamoto T, Iwamoto J, Mizumaki $\mathrm{K}$, Hashimoto $\mathrm{N}$, Inoue $\mathrm{H}$ : Bepridil reverses atrial electrical remodeling and L-type calcium channel downregulation in a canine model of persistent atrial tachycardia. J Cardiovasc Electrophysiol, 2007 ; 18(7) : $765 \sim 772$ 